\title{
RANCANG BANGUN SISTEM PEMESANAN CATERING DAN DEKORASI DI SUMBAWA BESAR BERBASIS ANDROID
}

\author{
${ }^{1}$ Rodianto, ${ }^{2}$ Arni Safitri \\ ${ }^{1,2}$ Program Studi Informatika, Universitas Teknologi Sumbawa \\ rodianto.mursali@gmail.com ${ }^{1}$, safitriarni23@gmail.com ${ }^{2}$
}

\begin{abstract}
The catering and decorating process in Sumbawa is still conventional. So that the service procedure which applied for now are still less effective and efficient. This process incude to the owners of catering and decoration that could does a mistake, among others, the double order, the order making was not in order due to the accumulation of order notes, especially when crowded customers ordered by telephone or short message which could occur human error such as forgetting the order customer, and pen or order paper that runs out. The software is built by using the programming languages PHP, MySQL, Java and Android Studio. The purpose of making this ordering system is to help the owner of catering nusiness and decoration in Sumbawa besar to improving the quality of their business in the eyes of customers. This ordering system has a service that makes customers know the that location of the place of residence of the business owner as to minimize the occurrence of customer concers for message that are not served. The method used is a method of data collection and software development. The software development process model is used in the waterfall model which consist (1) analysis, (2) design, (3) coding, (4) program testing, (5) maintance.
\end{abstract}

Keywords: Catering and decoration ordering system, Waterfall Method, Java, PHP, UML (Unified Modeling Language), MySQL, Android Studio

\begin{abstract}
ABSTRAK
Proses pemesanan catering dan dekorasi di sumbawa masih bersifat konvensional. Sehingga prosedur pelayanan yang diterapkan saat ini masih kurang efektif dan efisien. Proses tersebut menyebabkan para pemilik catering dan dekorasi yang bisa saja terjadi kekeliruan antara lain adanya pemesanan yang double, tidak urutnya pembuatan pemesanan akibat bertumpuknya nota pemesanan terutama pada saat ramai pelanggan yang memesan melalui telepon maupun pesan singkat yang bisa saja terjadi human error seperti lupa atas pesanan pelanggan, dan pena atau kertas pemesanan yang habis. Perangkat lunak dibangun menggunakan bahasa pemrograman PHP, MySQL, Java dan Android Studio.Adapun tujuan dari pembuatan sistem pemesanan ini adalah untuk membantu pemilik usaha catering dan dekorasi yang ada di Sumbawa besar dalam meningkatkan mutu dan kualitas usahaannya di mata para pelanggan. Dimana sistem pemesanan ini memiliki layanan yang membuat pelanggan mengetahui lokasi tempat tinggal pemilik usaha sehingga dapat meminimalisir terjadinya kehawatiran pelanggan atas pesananya yang tidak dilayani. Metode yang digunakan adalah metode pengumpulan data dan pengembangan perangkat lunak. Model proses pengembangan software digunakan model waterfall yang terdiri dari (1) analisis, (2) desain, (3) pengkodean, (4) pengujian program, (5) pemeliharaan.
\end{abstract}

Kata Kunci: Sistem Pemesanan Catering dan Dekorasi, Metode Waterfall, Java, php, UML (Unified Modeling Language), MySQL, Android Studio. 


\section{PENDAHULUAN}

\subsection{Latar Belakang}

Perkembangan teknologi internet saat ini semakin berkembang ditandai dengan semakin banyaknya suatu instansi atau perusahaan baik perusahaan mikro dan makro. Salah satu contohnya yaitu pada perusahaan mikro yang bergerak dibidang catering dan dekorasi. Untuk meningkatkan usaha tersebut dibutuhkan pengembangan serta penerapan teknologi yang ada dalam proses pelayanan pemesanan sehingga menjadi lebih cepat dan mudah serta memberikan kenyamanan bagi pelanggan. Usaha dibidang catering dan dekorasi di Sumbawa besar semakin berkembang dengan adanya penambahan jumlah usaha catering dan dekorasi yang bertambah. Usaha catering menyediakan pelayanan berupa pemesanan makanan seperti acara pernikahan, acara ulang tahun, acara khitanan, syukuran dan berbagai macam jenis acara lainnya. Sedangkan pada usaha dekorasi pelayanan yang diberikan berupa pemakaian baju adat, rias pengantin, dekorasi pengantin dan telah merambah ke bidang dekorasi untuk berbagai macam acara formal dan nonformal. Hal ini yang mendorong penulis untuk membuat "Rancang Bangun Sistem Pemesanan Catering dan Dekorasi di Sumbawa Besar Berbasis Android" yang diharapkan dapat membantu pemilik usaha catering dan dekorasi yang ada di Sumbawa besar dalam meningkatkan mutu dan kualitas usahaannya di mata para pelanggan. Sistem pemesanan ini memudahkan pelanggan dalam proses booking pesanan menggunakan smartphone serta pesanan tersebut akan masuk ke web admin. Sistem pemesanan ini memiliki layanan yang membuat pelanggan mengetahui lokasi tempat tinggal pemilik usaha sehingga dapat meminimalisir terjadinya kehawatiran pelanggan atas pesananya yang tidak dilayani.

\subsection{Tujuan Penelitian}

Tujuan dari penelitian ini yaitu untuk merancang dan membangun sistem pemesanan catering dan dekorasi berbasis android menggunakan android studio 2.3.3 dan basis data MySQL yang dapat membantu pelanggan dalam memesan atau membooking catering dan dekorasi dari masingmasing catering dan dekorasi yang telah dipilih baik melalui telepon atau pesan singkat.

\section{METODE PENELITIAN}

Metode analisa dan perancangan dalam penilitian ini merupakan kategori penelitian kualitatif yang bersifat deskriptif, Dimana framework yang digunakan adalah SDLC (Software Development Life Cycle) yang menjadi metode acuan dalam perancangan sistem. SDLC merupakan siklus pengembangan perangkat lunak yang didalamnya terdiri siklus proses yang berupa fase dari mekanisme yang dibutuhkan yang dilakukan secara bertahap dan berurutan, berikut ini adalah tahapan pengembangan sistem dalam SDLC:

\subsection{Analisis}

Pada tahapan ini dilakukan analisa kebutuhan dengan melakukan pengumpulan data dengan konsep deskriptif dan data kualitatif. Adapun langkah-langkah yang dilakukan adalah dengan menggunakan empat metode yaitu observasi, wawancara, dokumentasi dan studi pustaka. Berikut ini adalah hasil analisa perangkat yang dibutuhkan oleh sistem adalah:

Tabel 1. Analisa Kebutuhan Perangkat Keras

\begin{tabular}{|l|l|}
\hline Nama Perangkat Keras & \multicolumn{1}{|c|}{ Spesifikasi } \\
\hline & - Processor Intel ${ }^{\circledR}$ Core $^{\mathrm{TM}}$ i3-3217U CPU @ 1.80 \\
& GHZ \\
Personal Computer & RAM 6,00 GB \\
& $-\quad$ 64-bit Operating System \\
& - Radeon HD Graphics 8530M 1 GB \\
& - HDD 500 GB \\
\hline
\end{tabular}




\begin{tabular}{|l|l|}
\hline & - CPU Octa-core \\
\multirow{3}{*}{ Smartphone Android } & - RAM 2,00 GB \\
& - Meory Internal 32 GB \\
& - USB \\
& - Kabel Data \\
\hline
\end{tabular}

Untuk menunjang pembuatan sistem dibutuhkan berapa perangkat lunak yang kompatibel dengan perangkat keras diantaranya sebagai berikut:

Tabel 2. Analisa Kebutuhan Perangkat Lunak

\begin{tabular}{|c|c|}
\hline Nama Perangkat Lunak & Spesifikasi \\
\hline Sistem Operasi & $\begin{array}{ll}- & \text { Windows } 7(\mathrm{PC}) \\
- & \text { Android } 6.0\end{array}$ \\
\hline Tools Pemrograman & $\begin{array}{ll}\text { - } & \text { Andoid Studio 2.3.3 } \\
\text { - } & \text { Java Development Kit (JDK) } \\
\text { - } & \text { Android SDK } \\
\text { - } & \text { PHP } \\
\text { - } & \text { API (Application Programming Interface) }\end{array}$ \\
\hline Basis Data & MySQL \\
\hline Paket Interface Server & Xampp V3.2.2 \\
\hline
\end{tabular}

\subsection{Desain}

Proses desain ini menerjemahkan syarat kebutuhan ke sebuah perancangan software yang dapat diperkirakan sebelum dibuat coding. Proses ini berfokus pada perancangan desain interface web dan desain interface aplikasi android. Berikut ini adalah gambaran perancangan sistem secara umum:

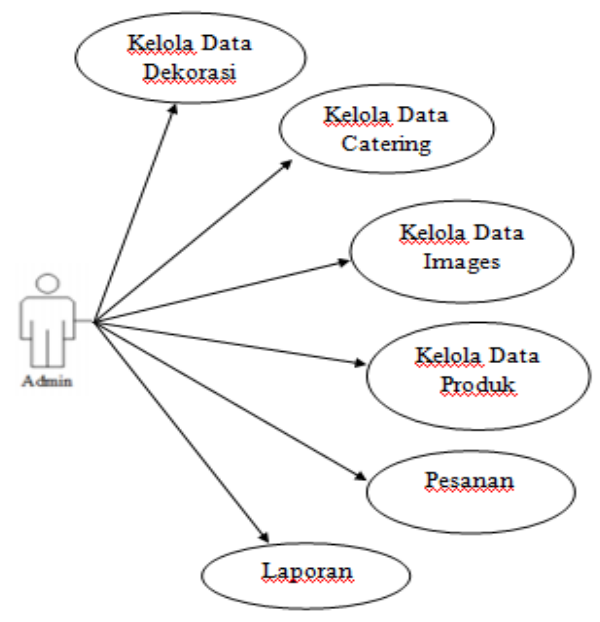

Gambar 1. Use case diagram untuk aktor admin

Gambar 1 adalah diagram use case pada sisi admin yang menggambarkan gambaran akses pada sisi admin untuk mengelola, disamping akses admin pada system ini juga terdapat akses client atau pengguna yang akan mengakses sistem untuk melakukan pemesanan melalui sistem. Berikut ini adalah gambaran diagram use case pada sisi client: 


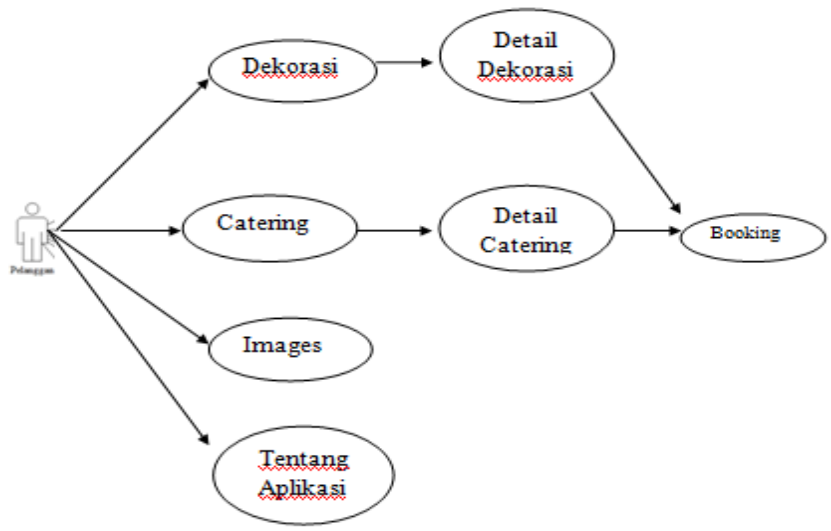

Gambar 2. Use case diagram untuk aktor pelanggan

Setelah selesai melakukan perancangan usecase, langkah selanjutnya adalah melakukan perancangan Activity diagram untuk menggambarkan aktivitas proses dalam sistem dan dilanjutkan dengan perancangan sequence diagram untuk menggambarkan hubungan antar proses (Process detailed) serta perancangan class diagram, berikut ini adalah rancangan Class Diagram seperti terlihat pada gambar berikut:

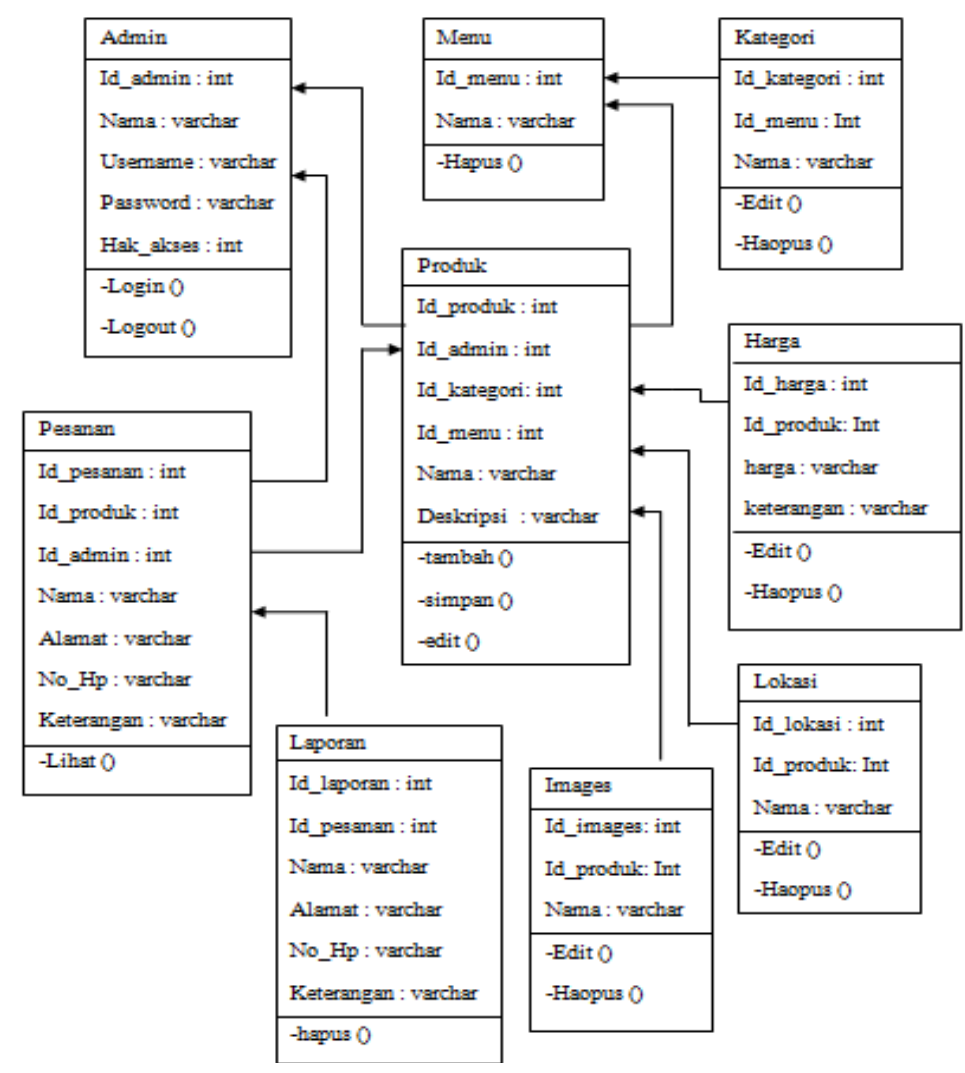

Gambar 3. Class Diagram Sistem

Diagram pada class diagram diatas menggambarkan hubungan proses antara aplikasi dengan basis data dan sekaligus menggambarkan gambaran struktur basis data secara umum yang terdapat pada sistem. berikut adalah gambaran umum rancangan basis data yang digunakan pada sistem. 
Tabel 3. Struktur Tabel Admin

\begin{tabular}{|c|c|c|c|}
\hline Nama Data & Tipe Data & Size & Keterangan \\
\hline Id_admin & Int & 3 & Berisi id pemilik \\
\hline Nama & Varchar & 50 & Berisi nama pemilik \\
\hline Username & Varchar & 50 & Berisi username pemilik \\
\hline Password & Varchar & 50 & Berisi password pemilik \\
\hline Hak_akses & Varchar & 11 & Berisi hak akses pemilik \\
\hline
\end{tabular}

Tabel 4. Struktur Tabel Menu

\begin{tabular}{|c|c|c|c|}
\hline Nama Data & Tipe Data & Size & Keterangan \\
\hline Id_menu & Int & 3 & Berisi id menu \\
\hline Nama & Varchar & 100 & Berisi nama menu \\
\hline
\end{tabular}

Tabel 5. Struktur Tabel Kategori

\begin{tabular}{|c|c|c|c|}
\hline Nama Data & Tipe Data & Size & Keterangan \\
\hline Id_kategori & Int & 6 & Berisi id kategori \\
\hline Id_menu & Int & 11 & Berisi id menu \\
\hline Nama & Varchar & 50 & Berisi nama kategori \\
\hline
\end{tabular}

Tabel 6. Struktur Tabel Produk

\begin{tabular}{|c|c|c|c|}
\hline Nama Data & Tipe Data & Size & Keterangan \\
\hline Id_produk & Int & 3 & Berisi id produk \\
\hline Id_menu & Int & 3 & Berisi id menu \\
\hline Id_kategori & Int & 4 & Berisi id kategori \\
\hline Id_admin & Int & 4 & Berisi id admin atau pemilik \\
\hline Nama & Varchar & 50 & Berisi nama produk \\
\hline Deskripsi & Varchar & 200 & Berisi deskripsi tiap produk \\
\hline
\end{tabular}

Tabel 7. Struktur Tabel Harga

\begin{tabular}{|c|c|c|c|}
\hline Nama Data & Tipe Data & Size & Keterangan \\
\hline Id_harga & Int & 11 & Berisi id harga \\
\hline Id_produk & Int & 11 & Berisi id produk \\
\hline Harga & Varchar & 100 & Berisi daftar harga \\
\hline Keterangan & Varchar & 100 & Berisi keterangan harga \\
\hline
\end{tabular}

Tabel 8. Struktur Tabel Lokasi

\begin{tabular}{|c|c|c|c|}
\hline Nama Data & Tipe Data & Size & Keterangan \\
\hline Id_lokasi & Int & 3 & Berisi id lokasi \\
\hline Id_produk & Int & 4 & Berisi id produk \\
\hline Lat & Float & 10.6 & Berisi latitude lokasi \\
\hline Lng & Float & 10.6 & Berisi longitude lokasi \\
\hline Lokasi & Varchar & 255 & Berisi alamat pemilik \\
\hline
\end{tabular}


Tabel 9. Struktur Tabel Pesanan

\begin{tabular}{|c|c|c|c|}
\hline Nama Data & Tipe Data & Size & Keterangan \\
\hline Id_pesanan & Int & 3 & Berisi id pemilik \\
\hline Id_produk & Int & 4 & Berisi id produk pemilik \\
\hline Id_admin & Int & 4 & Berisi id admin atau pemilik \\
\hline Nama & Varchar & 50 & Berisi nama pelanggan \\
\hline Alamat & Varchar & 200 & Berisi alamat pelanggan \\
\hline No_hp & Varchar & 20 & Berisi nomor telepon pelanggan \\
\hline Keterangan & Varchar & 200 & Berisi keterangan pesanan \\
\hline
\end{tabular}

Setelah selesai melakukan desain database langkah selanjutnya adalah membuat rancangan interface aplikasi sebagai acuan programmer dalam membuat program baik pada sisi admin (backend) maupun pada sisi klien (frontend).

\subsection{Pengkodean}

Pada tahap ini hasil rancangan akan diimplementasikan dalam bahasa pemrograman dengan menggunakan bahasa pemrograman Android yang digunakan untuk memprogram aplikasi pada sisi client (Frontend) dan dikolaborasi dengan bahasa pemrograman HTML 5 dan PHP untuk memprogram aplikasi pada sisi admin (backend) sebagai kendali sistem untuk melakukan manipulasi data dalam sistem dan melakukan konfigurasi keamanan system.

\subsection{Pengujian}

Sistem yang telah selesai dibangun melalui tahap coding, kemudian dilakukan penguujian. Hal ini dilakukan untuk memastikan bahwa perangkat lunak yang telah dibuat dapat digunakan dengan baik dan sudah layak pakai atau perlu disempurnakan lagi.

\subsection{Pendukung atau Pemeliharaan}

Tahapan ini bisa dikatakan selesai dalam pembuatan sebuah software atau sistem. Setelah melakukan analisis, perancangan, desain dan pengkodean maka sistem yang sudah jadi digunakan oleh user. Kemudian software yang telah dibuat harus dilakukan pemeliharaan secara berkala.

\section{HASIL DAN PEMBAHASAN}

\subsection{Hasil Penelitian}

Pada penelitian ini menghasilkan aplikasi berbasis web yang digunakan pada sisi admin yang digunakan untuk mengelola data aplikasi dan aplikasi berbasis android yang digunakan pada sisi klien. Gambar 4 merupakan tampilan implementasi ketika pengelola admin akan masuk dan mengakses panel admin.

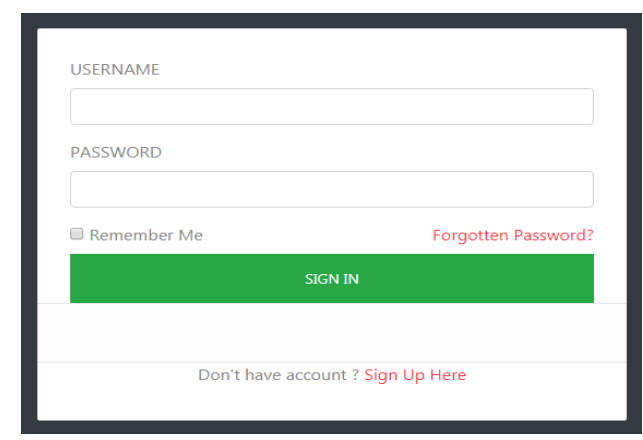

Gambar 4. Halaman Login Admin 
Setelah pengguna admin berhasil login akan lansung diarahkan ke halaman utama pada pada panel admin Dimana pada halaman tersebut terdapat beberapa menu yang digunakan untuk melakukan konfigurasi program serta beberapa fasilitas yang digunakan untuk menginput beberapa data yang dibutuhkan oleh aplikasi. Berikut ini adalah tampilan halaman utama aplikasi:

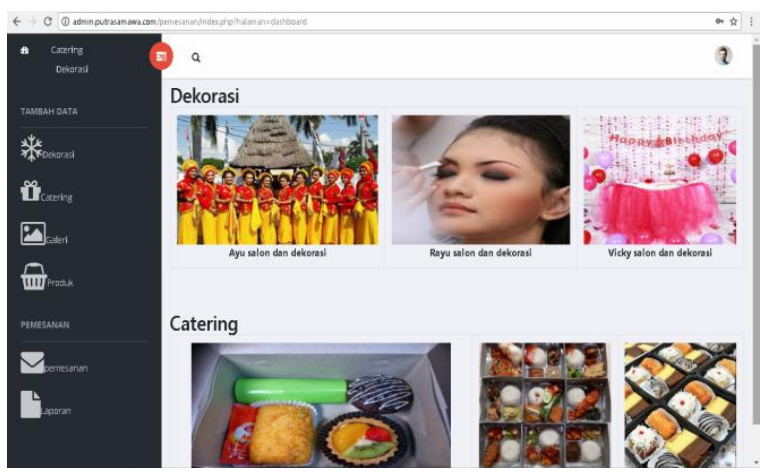

Gambar 5. Tampilan Halaman Utama panel admin

Pada halaman utama terdapat beberapa struktur menu yang digunakan untuk kelola data dekorasi, kelola data rias wajah, data kelola baju adat dan data kelola data catering. Hasil pengujian aplikasi yang dilakukan oleh peneliti dengan menggunakan metode pengujian Black Box menunjukan bahwa pengguna pada level admin dapat menggunakan fitur fitur menu yang terdapat pada aplikasi untuk melakukan inputan data seperti data Dekorasi, Data Rias Wajah, Data Penyewaan Bahu Adat serta Data Pengelolaan Catering seprti terlihat pada gambar berikut:

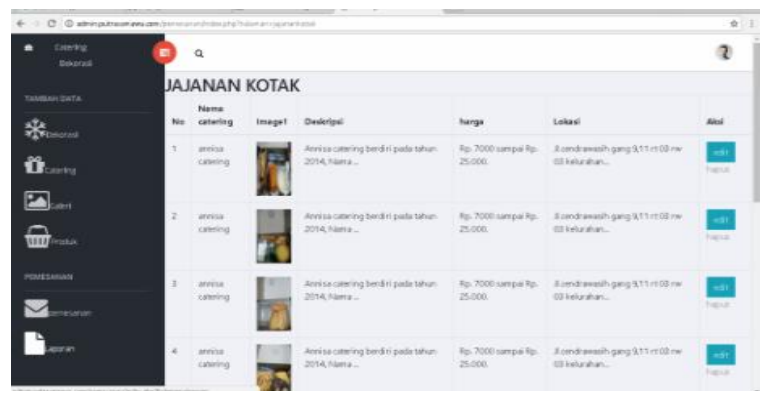

Gambar 6. Tampilan Inputan Data

Untuk mempermudah proses pemesanan oleh pelanggan dapat dilakukan dengan mengakses aplikasi berbasis android sebagai interface untuk melakukan interaksi dengan system, sehingga melalui melalui antarmuka aplikasi android dimungkinkan pelanggan melakukan pemesanan terhadap beberapa produk yang terdapat pada aplikasi. Berikut ini adalah antarmuka aplikasi android yang dapat digunakan oleh pelanggan untuk dapat melakukan pemesanan produk:

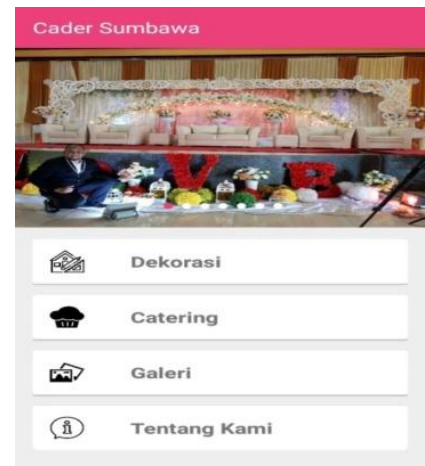

Gambar 7. Tampilan Halaman Utama Aplikasi Android 
Pada aplikasi android terdapat beberapa struktur menu yang dapat diakses oleh pelanggan diantaranya menu Dekorasi yang berisi daftar beberapa dekorasi yang menyediakan jasa dekorasi seprti dekorasi pengantin dan dekorasi khitanan, Menu catering, dan Rias wajah seperti terlihat pada gambar berikut ini:

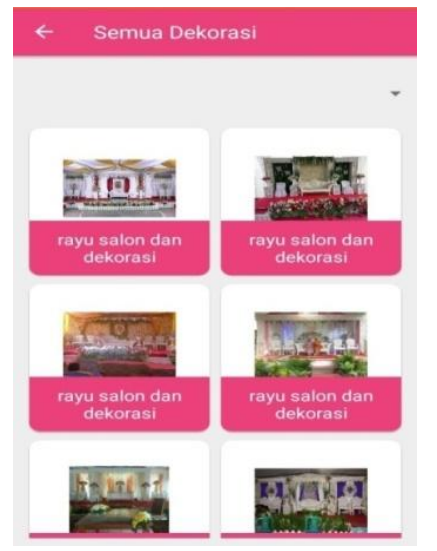

Gambar 8. Tampilan Menu Dekorasi

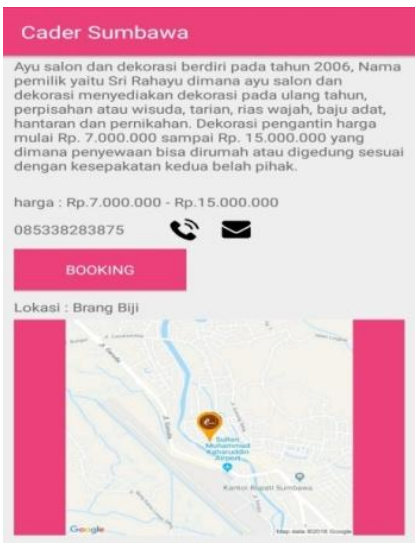

Gambar 9. Tampilan Detail Produk

\subsection{Pembahasan}

Setelah melakukan pengujian terhadap aplikasi dengan menggunakan metode black box testing, aplikasi dapat berfungsi dengan baik dan tidak ditemukan kesalahan fungsi pada program baik pada sisi backend (Pengguna admin) maupun pada sisi Frontend semua fitur aplikasi dapat digunakan dengan sempurna, misalnya ketika peneliti mencoba melakukan beberapa skenario diantaranya melakukan login ke panel admin maupun melakukan inputan data pada menu kategori,menu dekorasi dan menu catering semua fitur inputan dapat digunakan dengan baik tanpa menemui kesalahan pada menu inputan dan data hasil inputan berhasil dikirimkan ke database.

Supaya aplikasi dapat digunakan secara online peneliti mengpload aplikasi ke webhosting serta memasukan aplikasi mengapload aplikasi APK nya ke Google play store supaya dapat diinstal di smartphone android dan bisa digunakan oleh masyarakat secara luas.

\section{KESIMPULAN DAN SARAN}

\subsection{Kesimpulan}

Kesimpulan yang dapat diambil dari penulisan ini yaitu Sistem Pemesanan Catering dan Dekorasi di Sumbawa Berbasis Android sudah berhasil dibangun dengan menggunakan android studio 2.3.3 dan database MySQL. Setelah dilakukan uji coba dengan smartphone telah berhasil mencari menu catering, menu dekorasi, galeri dan tentang kami. Dengan demikian, maka penelitian ini dapat membantu masyarakat Sumbawa maupun masyarakat luar sumbawa dalam mencari informasi mengenai catering dan dekorasi di Sumbawa berbasis android.

\subsection{Saran}

Adapun untuk pengembangan lebih lanjut pada penelitian ini, disarankan hal-hal sebagai berikut yaitu penambahan kelola blog dan akun, sistem validasi pelanggan yang baru mendaftar untuk menjadi member sehingga proses sistem pemesanan catering dan dekorasi dengan menggunakan aplikasi dapat dilakukan dengan aman dan nyaman 


\section{DAFTAR PUSTAKA}

[1] Arifin. 2010. "Dashboard untuks persentasi bisnis". Yogyakarta

[2] Betha Sidik, 2012. "Pemrograman Web dengan PHP". informatika, Bandung.

[3] Dharwiyanti, Sri. 2003. Pengantar Unified Modeling Languange (UML). Dari: http://www.ilmukomputer.org/wp-content/uploads/2006/08/yanti-uml.zip,24 September 2012.

[4] Jogiyanto. (2005) "Pengenalan Sistem Informasi Edisi Revisi". Yogyakarta: Penerbit Andi.

[5] Juhara, Zamrony P. (2016). "Panduan Lengkap Pemrograman Android". Yogyakarta: Andi.

[6] Kadir, Abdul, 2008."Dasar Pemrograman Web Dinamis Dengan PHP - Edisi Revisi". Yogyakarta: Andi. 